\title{
Energy and Protein Intake During Pregnancy in Relation to Preterm Birth: ACase Control Study
}

\author{
Shally Awasthi, M Chauhan, M Pandey, S Singh AND *U Singh \\ From Department of Pediatrics and *Obstetrics and Gynecology, King George's Medical University, Lucknow, UP, India. \\ Correspondence to: Dr Shally Awasthi, Professor, Department of Pediatrics, King George‘s Medical University, Lucknow, \\ UttarPradesh,India.Shally07@gmail.com \\ Received: August 02, 2014; Initial review: September 08, 2014; Accepted: March 10, 2015.
}

Objective: To find the association of maternal energy and protein intake with preterm birth.

Design: Case-control study.

Setting: Two hospitals at Lucknow in Northern India.

Participants: Cases ( $n=350$ ) were defined as mothers (age 18-40 y) of singleton live preterm ( $<37 \mathrm{wks}$ ) neonates. Controls $(n=350)$ were mothers who delivered a singleton neonate, consecutive to enrolled case, after completing 37 weeks of gestation.
Results: There was a statistically significant lower mean (SD) energy intake [cases 1624 (249) Kcal vs. controls 1911 (341) Kcal; $P<0.001$ ] and protein intake [cases 32.1 (6.1) vs. controls 37.2 (7.0); $P<0.001]$ among women who delivered preterm neonates. Maternal energy and protein intake had significant positive correlation with neonatal weight, length, foot length, head circumference and chest circumference.

Conclusion: Lower energy and protein intake during pregnancy is possibly associated with preterm birth.

Keywords: Diet, Low birth weight, Prematurity.
$\mathrm{P}$ reterm birth is a major determinant of neonatal mortality and childhood morbidity [1] There seems to be an upward trend [2,3], which contributes to almost 3.6 million preterm births accounting for $23.6 \%$ of the global preterm births reported each year [4]. Preterm birth has been consistently associated with maternal underweight and nutrient deficiencies during pregnancy [5-9]. Therefore, nutritional assessment needs to be an integral part of antenatal care and should be continued during pregnancy in order to reduce the risk of maternal, fetal and neonatal complications, as well as the short- and long-term adverse outcomes. We conducted this case-control study with the objective to find the association of maternal energy and protein intake with preterm birth.

\section{Methods}

This was a hospital-based case-control study conducted in King George's Medical University, a tertiary-care teaching institute, and Ram Manohar Lohia Hospital, a tertiary-care government non-teaching institute, in Lucknow, Uttar Pradesh, India. These two hospitals were chosen on the basis of their highest delivery data per year. Ethical clearance for the study was obtained from the Institutional ethical committee of King George's Medical University. Written informed consent was obtained from participating mothers.
The gestational age of neonate was assessed by using modified Ballard score within 48 hours of birth [10]. Preterm was defined as birth less than 37 weeks of gestation [1]. Cases were defined as mothers (age 18-40 years) of live preterm neonates. Controls were eligible mothers who delivered a neonate at or after 37 weeks of gestation, consecutive to an enrolled case. Mothers who gave birth to twins or those with neonates having congenital abnormalities were excluded.

To detect a mean difference of $5 \mathrm{gm} /$ day (SD $7 \mathrm{~g}$ ) in protein intake (two sided $\alpha=0.05$, power $=90 \%$ ), we required a sample of 292 women each for cases and controls. We planned to recruit 350 cases and 350 controls.

Medical records were reviewed to obtain the age, pregnancy details and illness status of included women. Data were collected by a trained Medical scientist. Socioeconomic status was defined using Modified Kuppuswamy's socioeconomic scale 2012 [11]. Social classes I and II were categorized as high, III as middle, and IV and $V$ as low. Mothers were asked for their daily intake of supplements (Iron, folic acid, vitamin D and calcium) during pregnancy. A predesigned questionnaire was used for obtaining the information of their diet in one week preceding delivery. The questions were pertaining to intake of milk, lentils, wheat products, rice, fruit vegetables, fast food, meat products and Indian desserts. 
Food frequencies for individual questions were converted into servings for a day or week, and then summed to give a total daily (or weekly) intake of protein and energy. Quantity was assessed by showing them household measurements like katoris, teaspoon and glass of standard sizes. Nutritional assessment was done on the basis of guidelines given by National Institute of Nutrition [12].

All neonates were weighed on a weighing machine corrected to one digit after decimal under the supervision of pediatrician, within 48 hours of delivery. Neonatal length was measured with infantometer. Neonatal foot length, head circumference and chest circumference were measured within 48 hours by non-stretchable measuring tape. Maternal Mid Upper Arm Circumference (MMUAC) was also obtained by non-stretchable measuring tape.

Statistical Analysis: Data were analyzed by SPSS version 14.0. Categorical data were compared by Chi-square test, and Student's $t$ test was applied for continuous variables. Pearson's correlation coefficient was applied to analyze the correlation of maternal diet with various anthropometric variables of newborn. $P$ value of $<0.05$ was considered to be significant.

\section{Results}

A total of 700 mothers (350 with preterm delivery and 350 with term delivery) from both hospitals (240 cases and controls each from King George's Medical University and 110 cases and controls each from Ram Manohar Lohia Hospital) were recruited from April 2012 to April 2014 (Fig. 1).

Table I shows the sociodemographic and anthropometric characteristics of cases and control mothers and their newborns. Cases had lower Maternal Mid Upper Arm Circumference (MMUAC) and lower post-delivery maternal weight.

Table II shows the dietary intake of mother in the week preceding the delivery. Mothers who delivered neonates before 37 weeks of gestation consumed lesser energy than the mothers who delivered term neonates [1624 (240) Kcal vs. 1911 (341) Kcal; $(P<0.001)$. Mothers with term neonates consumed significantly more servings of wheat, lentils, vegetables and fruits than mothers with preterm neonates. Positive correlation was also observed between neonatal anthropometric measures (head circumference, chest circumference, neonatal whole length, foot length and weight), and maternal energy and protein intake (Table III).

Positive correlation was also observed between maternal anthropometric measures and energy intake. Maternal daily energy intake was positively associated

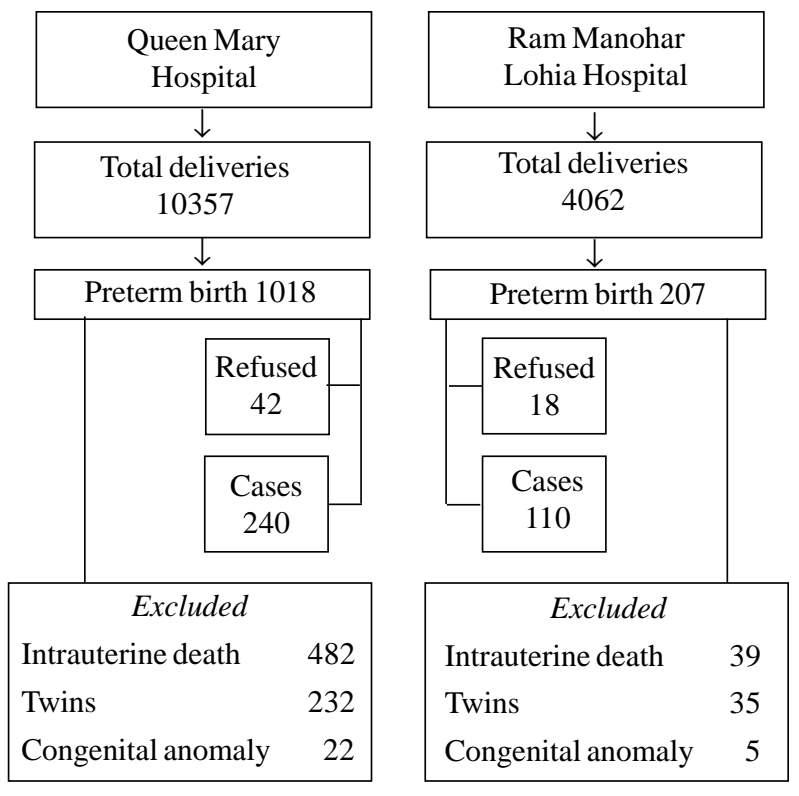

FIG.1 Flowchart showing recruitment of cases.

with maternal weight $(\mathrm{r}=0.2, P=0.001)$ and MMUAC $(\mathrm{r}=0.2, P<0.001)$. Protein intake was also significantly correlated with maternal weight $(\mathrm{r}=0.2, P<0.001)$ and MMUAC ( $\mathrm{r}=0.1, P=0.002)$.

\section{Discussion}

In this case-control study, we observed a statistically significant association of preterm birth with lesser maternal energy and protein intake. Maternal energy and protein intake also positively correlated with neonatal head circumference, chest circumference, birth weight, whole length and foot length.

The limitation of this study was that information of dietary intake in last one week was collected which is unlikely to capture the nutritional intake during entire pregnancy. To overcome the limitation of paucity of information on maternal diet, we also measured Maternal Mid Upper Arm Circumference which is reported to be a potential indicator of chronic nutritional status [13]. Recall method for estimating dietary intake and approximation of quantity of food consumed were the other limitations. The likely effect of other maternal, placental and fetal factors leading to preterm birth was also not evaluated in our study.

Our findings are supported by a Cochrane review that concluded that less energy intake during pregnancy is strongly associated with poor fetal growth, and underweight during pregnancy can also be possibly associated with the risk of preterm birth [14]. On the other hand, meta-analysis of five trials on balanced protein 
TABLE I SOCIO-DEMOGRAPHIC AND ANTHROPOMETRIC CHARACTERISTICS OF CASES AND Controls

\begin{tabular}{|c|c|c|c|c|}
\hline Characteristics & Case $(n=350)$ & Control $(n=350)$ & Pvalue & $O R(95 \% C I)$ \\
\hline \multicolumn{5}{|l|}{ Maternal } \\
\hline age $(y)$, mean & $26(4.3)$ & $25.4(3.8)$ & 0.07 & $1.0(0.9-1.0)$ \\
\hline weight (Kg), mean (SD) & $52.1(6.7)$ & $57.0(5.9)$ & $<0.001$ & $0.8(0.8-0.9)$ \\
\hline Mid upper arm circumference (cm), mean (SD) & $23.4(2.3)$ & $24.4(1.9)$ & $<0.001$ & $0.8(0.7-0.8)$ \\
\hline Vegetarian diet, n (\%) & $210(60.7 \%)$ & $232(66.3 \%)$ & 0.12 & $0.7(0.5-1.0)$ \\
\hline Illiterate, $n(\%)$ & $283(80.9 \%)$ & $3(0.9 \%)<0.001$ & 488.5 & $(152.0-1570.0)$ \\
\hline Housewife & $334(95.4 \%)$ & $320(91.4 \%)$ & 0.04 & $1.9(1.0-3.6)$ \\
\hline \multicolumn{5}{|l|}{ Socio Economic Status } \\
\hline Middle (III) & $123(25.7 \%)$ & $104(30.2 \%)$ & 0.005 & $1.7(1.1-2.5)$ \\
\hline Lower (IV and V) & $139(39.4 \%)$ & $117(33.9 \%)$ & 0.003 & $1.7(1.2-2.8)$ \\
\hline \multicolumn{5}{|l|}{ Neonatal } \\
\hline Gestational age (wk), mean (SD) & 33.7 (1.9) & $38.4(1.0)$ & & \\
\hline Weight (g), mean (SD) & $1850.8(378.4)$ & $2820(425.9)$ & & \\
\hline Whole length (cm), mean (SD) & $43(2.4)$ & $46.9(3.7)$ & & \\
\hline Foot length (cm), mean (SD) & $6.3(0.6)$ & $7.6(2.8)$ & & \\
\hline Head circumference $(\mathrm{cm})$, mean (SD) & $30.3(1.6)$ & $33.25(1.1)$ & & \\
\hline Chest circumference (cm), mean (SD) & $28.0(1.6)$ & $31.18(1.1)$ & & \\
\hline
\end{tabular}

TABLE II COMPARISON OF DiETARy INTAKe BetweEn CASES AND CONTROLS

\begin{tabular}{lllr}
\hline Diet & \multicolumn{1}{c}{$\begin{array}{c}\text { Cases } \\
\text { Mean (SD) }\end{array}$} & \multicolumn{1}{c}{$\begin{array}{c}\text { Controls } \\
\text { Mean (SD) }\end{array}$} & $<$ value \\
\hline Energy (Kcal/day) & $1624(249)$ & $1911(341)$ & $<0.001$ \\
Protein (g/day) & $32(6.0)$ & $37.2(7.0)$ & $175(45)$ \\
Milk (mL/day) & $174(66)$ & $4.4(3.6)$ & $<0.8$ \\
White clarified butter (g/day) & $2.2(2.9)$ & $73.8(28.5)$ & $<.001$ \\
Lentils (g/day) & $67.6(26.2)$ & $147.1(33.2)$ & $<0.001$ \\
Wheat (g/day) & $136.4(29.5)$ & $241.5(79.2)$ & $<0.001$ \\
Cooked rice (g/day) & $205.5(87.3)$ & $323.1(93.3)$ & $<0.001$ \\
Vegetables (g/day) & $284(83.6)$ & $2.0(0.4)$ & 0.3 \\
Fish (pieces/week) & $3.4(1.1)$ & $2.2(0.6)$ & 0.8 \\
Chicken (pieces/week) & $2.4(2.2)$ & $1.8(0.3)$ & 0.5 \\
Mutton (pieces/week) & $2(0.7)$ & $5.3(1.7)$ & 0.5 \\
Dry fruits (no./week) & $5.4(2.2)$ & $1.8(0.8)$ & 0.1 \\
Indian desserts (no./week) & $1.6(0.5)$ & $1.8(0.4)$ & 0.9 \\
Fruits (no./week) & $1.5(0.3)$ & & \\
\hline
\end{tabular}

energy supplementation during pregnancy showed no difference between the incidence of term and preterm birth [15].

Our findings of positive correlation between maternal energy and protein intake and neonatal anthropometric measures are supported by another Indian study, reporting association of higher energy intake during pregnancy with birth weight [16]. Walker, et al. [17] reported that weight of the mother during pregnancy was associated with higher head circumference, chest circumference and whole length of neonate.

We conclude that lesser protein and energy intake is possibly associated with preterm birth. Although etiology of preterm birth is multi-factorial, maternal nutrition being 
TABLE III Correlation of Neonatal Anthropometric Measurements with Maternal Dietary InTAKe AND ANTHRopometric MEASUREMENTS

\begin{tabular}{lllllll}
\hline & \multicolumn{5}{c}{ Pearson Correlation Coefficient (P value) } \\
\cline { 2 - 7 } & $\begin{array}{c}\text { Neonatal } \\
\text { weight }\end{array}$ & $\begin{array}{c}\text { Neonatal } \\
\text { Whole length }\end{array}$ & $\begin{array}{c}\text { Foot } \\
\text { length }\end{array}$ & $\begin{array}{c}\text { Head } \\
\text { circumference }\end{array}$ & $\begin{array}{c}\text { Chest } \\
\text { circumference }\end{array}$ & $\begin{array}{c}\text { Gestational } \\
\text { age }\end{array}$ \\
\hline Post delivery maternal weight & $0.3(<0.001)$ & $0.2(<0.001)$ & $0.1(<0.001)$ & $0.3(<0.001)$ & $0.3(<0.001)$ & $0.3(<0.001)$ \\
Maternal mid upper arm circumference & $0.2(<0.001)$ & $0.1(<0.001)$ & $0.2(<0.001)$ & $0.2(<0.001)$ & $0.2(<0.001)$ & $0.2(<0.001)$ \\
Maternal energy intake & $0.2(<0.001)$ & $0.2(<0.001)$ & $0.06(0.07)$ & $0.3(<0.001)$ & $0.4(<0.001)$ & $0.4(<0.001)$ \\
Maternal protein intake & $0.2(<0.001)$ & $0.2(<0.001)$ & $0.1(0.01)$ & $0.3(<0.001)$ & $0.4(<0.001)$ & $0.3(<0.001)$ \\
\hline
\end{tabular}

\section{What Is ALREAdy KnOWn?}

- Poor maternal nutritional status is a cause of low birth weight.

What This Study Adds?

- Lower protein and energy intake during pregnancy is associated with preterm birth.

a modifiable factor can be used in public health interventions to prevent preterm deliveries.

Contributors: All authors have contributed, designed and approved the manuscript.

Funding: Indian Council of Medical Research (5/7/513/10RHN); Competing interests: None stated.

\section{REFERENCES}

1. Preterm birth Fact sheet. $\mathrm{N}^{\circ} 363$, WHO, Available from: http://www.who.int/ media centre / factsheets/fs363/en. Accessed November 28, 2014.

2. Piso B, Koss IZ, Winkler R. Antenatal interventions to reduce preterm birth: An overview of Cochrane systematic reviews. BMC Res Notes. 2014; 23: 265.

3. Howson EC, Kinney MV, Lawn JE. Born Too Soon: The Global Action Report on Preterm Birth. World Health Organization. Geneva, 2012.

4. Indian Foundation of Premature. Available from: http:// www.dayofbangalore.com/news/healthcare/indianfoundation-premature-babies-ifpb-marks-worldprematurity. Accessed November 28, 2014.

5. Bhattacharya S, Campbell DM, Liston WA, Bhattacharya S. Effect of body mass index on pregnancy outcomes in nulliparous women delivering singleton babies. BMC Public Health. 2007;7:168-73.

6. Dietz PM, Callaghan WM, Cogswell ME, Morrow B, Ferre C, Schieve LA. Combined effect of pre-pregnancy body mass index and weight gain during pregnancy on the risk of preterm delivery. Epidemiology. 2006;17:170-7.

7. Cnattingius S, Bergstrom R, Lipworth L, Kramer MS. Prepregnancy weight and the risk of adverse pregnancy outcomes. N Engl J Med. 1998;338:147-52.

8. McDonald SD, Han Z, Mulla S, Beyene J; Knowledge Synthesis Group. Overweight and obesity in mothers and risk of preterm birth weight infants: Systematic review and meta-analysis. BMJ. 2010;341:c3428.

9. Xinxo S, Bimbashi A, Kakarriqi EZ, Zaimi E. Association between maternal nutritional status of pre pregnancy, gestational weight gain and preterm birth. Mater Sociomed. 2013;25:6-8.

10. Ballard JL, Khoury JC, Wedig K, Wang L, EilersWalsman BL, Lipp R. New Ballard Score, expanded to include extremely premature infants. J Pediatr. 1991;119:417-23.

11. Bairwa M, Rajput M, Sachdeva M. Modified Kuppuswamy's socioeconomic scale: Social researcher should include updated income criteria, 2012. Indian J Community Med. 2013:38:185-6.

12. Dietary Guidelines for Indians. National Institute of Nutrition. 2010. Available From: http://ninindia.org/ DietaryguidelinesforIndians-Finaldraft.pdf. Accessed November 28, 2014.

13. Ricalde AE, Velasquez-Melendez G, Tanaka AC, De siqueria AA. Mid upper arm circumference in pregnant women and its relation to birth weight. Reu Saude Publica. 1998:112-7.

14. Kramer MS, Kakuma R. Energy and protein intake in pregnancy. Cochrane Databse Syst Rev. 2003;4:CD000032.

15. Villar J, Merialdi M, Gulmezoglu AM, Abalos E, Carroli $\mathrm{G}$, Kulie $\mathrm{R}$, et al. Nutritional interventions during pregnancy for the prevention or treatment of maternal morbidity and preterm delivery: An overview of randomized controlled trials. J Nutr. 2003;133:1606-25.

16. Bhatia BD, Banerjee D, Agarwal DK, Agarwal K. Fetal growth: Relationship with maternal dietary intakes. Indian J Pediatr. 1983;50:113-20.

17. Walker SP, Ewan-Whyte C, Chang SN, Powell CA, Feltcher H, Donald DM, et al. Factors association with size and proportionality at birth in term Jamaican infants. J Health Popul Nutr. 2003;21:117-26. 